\title{
Profitabilitas Sebagai Pemoderasi Pengaruh Pengungkapan Corporate Social Responsibility Pada Nilai Perusahaan
}

\author{
Kadek Gita Amdika Putri ${ }^{1}$ \\ Fakultas Ekonomi dan Bisnis \\ Universitas Udayana, Indonesia \\ Email: gitaamdikaputri@gmail.com
}

\author{
Made Gede Wirakusuma ${ }^{2}$ \\ Fakultas Ekonomi dan Bisnis \\ Universitas Udayana, Indonesia
}

\begin{abstract}
ABSTRAK
Salah satu faktor yang memengaruhi nilai perusahaan yaitu Corporate Social Responsibility (CSR). Adanya inkonsistensi hasil penelitian diharapkan profitabilitas mampu memperkuat CSR dalam meningkatkan nilai perusahaan. Tujuan penelitian ini untuk mendapatkan bukti empiris mengenai profitabilitas sebagai pemoderasi pengaruh CSR pada nilai perusahaan sektor pertambangan yang terdaftar di BEI periode 2016-2018. Metode penentuan sampel yang digunakan adalah metode nonprobability sampling dengan teknik purposive sampling. Jumlah perusahaan yang memenuhi kriteria adalah 11 perusahaan dengan jumlah amatan sebanyak 43 . Teknik analisis data yang digunakan adalah Moderated Regression Analysis. Hasil penelitian menemukan bahwa CSR tidak berpengaruh pada nilai perusahaan. Profitabilitas memperkuat pengaruh CSR pada nilai perusahaan. Hasil penelitian ini diharapkan mampu memberikan informasi bagi pihak-pihak yang berpekentingan sebagai dasar pengambilan keputusan investasi.
\end{abstract}

Kata Kunci: Nilai Perusahaan; Corporate Social Responsibility; Profitabilitas.

\section{Profitability as Moderation of Corporate Social Responsibility Disclosure Effect on Firm Value}

\section{ABSTRACT}

One of the factors that effect a firm value is Corporate Social Responsibility (CSR). The inconsistency of research results is expected to be able to strengthen CSR profitability in increasing company value. The purpose of this study is to obtain empirical evidence about profitability as a moderating effect of CSR on the value of the mining sector companies listed on the Stock Exchange in the 2016-2018 period. The sampling method used is the nonprobability sampling method with a purposive sampling technique. The number of companies that met the criteria was 11 companies with a total of 43 observations. The data analysis technique used was Moderated Regression Analysis. The results found that CSR not has a effect on firm value. Profitability strengthen the influence of CSR on firm value. The results of this study are expected to be able to provide information for interested parties as a basis for investment decision making.

Keywords: Firm Value; Corporate Social Responsibility; Profitability.

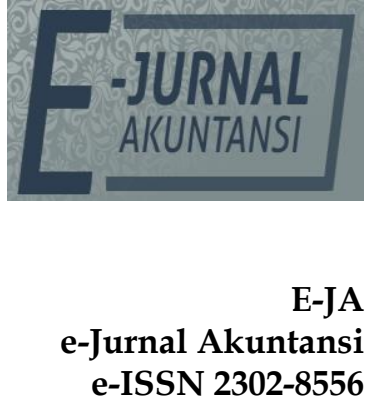

Vol. 30 No. 1

Denpasar, Januari 2020

Hal. 28-38

Artikel Masuk:

9 Oktober 2019

Tanggal Diterima: 8 November 2019 


\section{PENDAHULUAN}

Setiap perusahaan memiliki tujuan untuk meningkatkan nilai perusahaan. Nilai perusahaan akan mencerminkan keadaan perusahaan saat ini serta dapat menggambarkan prospek perusahaan di masa mendatang. Sehingga nilai perusahaan dianggap mampu memengaruhi penilaian para investor terhadap perusahaan (Sari, 2016). Nilai perusahaan merupakan persepsi investor terhadap tingkat keberhasilan perusahaan untuk dapat memberikan kemakmuran pemegang saham secara maksimum dengan meningkatnya harga saham perusahaan (Indasari, 2018). Sehingga nilai perusahaan merupakan hal utama yang diperhatikan oleh investor sebelum melakukan investasi.

Perkembangan dunia bisnis saat ini mengalami kemajuan yang sangat pesat serta persaingan yang begitu ketat. Seiring dengan perusahaan yang semakin berkembang, maka tingkat kesenjangan sosial dan kerusakan lingkungan semakin tinggi, hal itu terjadi karena adanya aktivitas perusahaan yang tidak terkendali terhadap berbagai sumber daya (Makalew, 2017). Perusahaan harus mampu menyeimbangkan antara tujuan ekonomi dengan tanggung jawab terhadap lingkungan dan sosialnya agar dapat diterima baik oleh masyarakat (Lingga, 2019). Menurut Latupono (2015) semakin bertanggungjawab perusahaan akan lingkungannya, maka citra perusahaan menjadi semakin baik. Apabila perusahaan memiliki citra yang baik dimata masyarakat, maka perusahaan akan dapat meningkatkan loyalitas konsumen terhadap perusahaan, sehingga secara tidak langsung akan meningkatkan nilai perusahaan (Nahda \& Harjito, 2011).

Nilai perusahaan dipengaruhi oleh dua faktor yaitu faktor keuangan dan non keuangan. Salah satu faktor non keuangan yang dapat memengaruhi nilai perusahaan yaitu Corporate Social Responsibility (CSR). Menurut World Business Council for Sustainable Development, CSR merupakan komitmen berkesinambungan dari kalangan bisnis untuk berperilaku etis dan memberi kontribusi bagi pembangunan ekonomi, seraya meningkatkan kualitas kehidupan karyawan dan keluarganya, serta komunitas lokal dan masyarakat luas pada umumnya. CSR adalah tanggung jawab perusahaan terhadap sosial dan lingkungan atas operasi bisnis yang dilakukan oleh perusahaan berdasarkan konsep triple bottom lines, yaitu profit, people, planet (Maqbool \& Zameer, 2018). Manfaat dari pengungkapan CSR adalah memberikan gambaran kepada pengguna informasi laporan keuangan khususnya investor, mengenai hubungan antara aspek ekonomi, lingkungan, dan sosial perusahaan, sehingga dapat menentukan keputusan untuk strategi kedepannya. Semakin besar perhatian perhatian perusahaan terhadap lingkungan sekitar maka semakin tinggi kepedulian masyarakat terhadap kinerja mereka, sehingga perusahaan akan memperoleh legitimasi.

Pentingnya melakukan kegiatan CSR di Indonesia telah diatur dalam Undang - Undang Perseroan Terbatas No. 40 Tahun 2007 tentang Perseroan Terbatas pada pasal 66 dan 74. Pasal 66 ayat (2) disebutkan bahwa selain menyampaikan laporan keuangan, perusahaan diwajibkan melaporkan tanggung jawab sosial dan lingkungan. Sedangkan pada pasal 74 menjelaskan kewajiban untuk melaksanakan tanggung jawab sosial dan lingkungan bagi 
perusahaan yang kegiatannya berkaitan dengan sumber daya alam. Hal ini menunjukkan bahwa CSR merupakan kewajiban bagi perusahaan.

Salah satu sektor perusahaan yang memiliki peranan penting dalam pengungkapan pertanggungjawaban sosialnya adalah perusahaan sektor pertambangan. Hal ini karena dalam menjalankan kegiatan bisnisnya, perusahaan sektor pertambangan akan bersentuhan langsung dengan pemanfaatan sumber daya alam yang mana berdampak langsung pada lingkungan. Indonesia merupakan salah satu negara dengan kekayaan sumber daya alam yang melimpah, salah satunya adalah bahan tambang. Sehingga banyak investor yang tertarik untuk berinvestasi di sektor ini. Namun, menurut Wahana Lingkungan Hidup Indonesia (WALHI) menilai perusahaan pertambangan paling berkontribusi besar terkait dengan kerusakan alam yang terjadi di kawasan Indonesia (Fibrianti, 2015). Hal ini terjadi karena segala aktivitas perusahaan pertambangan memanfaatkan lingkungan sumber daya yang ada sehingga pertanggungjawaban perusahaan terhadap lingkungan cukup besar.

Salah satu contoh kasus terkait pelaksanaan CSR yang terjadi di Indonesia yaitu pada tanggal 25 Desember 2017 harga saham INKP ditutup melemah Rp310 (-7.20\%) ke level Rp3.990 hal ini diduga akibat pencemaran lingkungan yang ditimbulkan oleh INKP di Perawang, Kabupaten Siak (www.sahamonline.id). INKP diketahui telah menggunakan bahan klorin, yang sangat berbahaya karena mampu membunuh makhluk hidup yang menghirupnya secara perlahan. Selain itu, kasus pertambangan yang baru saja kembali diperbincangkan yakni selama tahun 2018 terdapat 8 juta hektar (sekitar 3500 lubang) bekas galian tambang belum direklamasi (Image, 2019). Hal ini membuktikan bahwa kerusakan lingkungan yang diakibatkan dari kegiatan perusahaan akan membuat citra negatif di mata investor sehingga mempengaruhi nilai perusahaan.

Pelaksanaan CSR oleh perusahaan harus selaras dengan norma-norma, nilai, dan keyakinan yang berlaku di masyarakat sehingga perusahaan akan mendapatkan legitimasi (Nègre, et al., 2017). Legitimasi penting bagi perusahaan karena berhubungan dengan kelangsungan hidup perusahaan. Ketika terjadi ketidakselarasan nilai sosial dan norma perusahaan, maka perusahaan akan dapat kehilangan legitimasinya, yang selanjutnya akan mengacam kelangsungan hidup perusahaan. Perusahaan yang mampu memenuhi kontrak sosial maka keberadaan perusahaan akan direspon positif oleh masyarakat. Legitimasi ini akan meningkatkan reputasi perusahaan yang pada akhirnya akan berpengaruh pada nilai perusahaan (Retno, 2017). Hal ini menunjukkan bahwa nilai perusahaan dapat ditingkatkan dengan menyelaraskan bisnis perusahaan melalui program CSR yang efektif (Jitmaneeroj, 2017). Sejalan dengan hasil penelitian yang dilakukan Citra (2017) dan Sulistyaningsih (2017) menemukan bahwa CSR berpengaruh positif pada nilai perusahaan. Hasil penelitian tersebut bertentangan dengan hasil penelitian Inastri (2017) dan Kusumayanti (2016) menunjukkan bahwa CSR tidak berpengaruh pada nilai perusahaan.

Adanya inkonsistensi hasil penelitian sebelumya mengenai pengaruh CSR pada nilai perusahaan menjadi dasar dan motivasi untuk memasukkan profitabilitas sebagai variabel pemoderasi. Profitabilitas merupakan salah satu 
faktor keuangan yang memengaruhi nilai perusahaan. Profitabilitas adalah kemampuan suatu perusahaan untuk menghasilkan laba selama periode tertentu. Perusahaan dengan tingkat profitabilitas yang lebih tinggi akan memberikan peluang return yang lebih tinggi pula bagi para investor. Profitabilitas yang tinggi menunjukkan prospek perusahaan yang baik, sehingga investor akan merespon positif sinyal tersebut dan pada akhirnya dapat meningkatkan nilai perusahaan (Puspita, 2018). Profitabilitas digunakan karena semakin tinggi tingkat profitabilitas yang dicapai perusahaan maka semakin kuat pula hubungan pengungkapan sosial dengan nilai perusahaan.

Menurut World Business Council Sustainable Development (WBCSD) CSR adalah komitmen berkelanjutan oleh perusahaan untuk berperilaku etis dan berkontribusi terhadap pembangunan ekonomi sambil meningkatkan kualitas hidup tenaga kerja serta masyarakat setempat dan masyarakat luas (www.gaea.bg). CSR adalah tanggung jawab perusahaan terhadap sosial dan lingkungan atas operasi bisnis yang dilakukan oleh perusahaan berdasarkan konsep triple bottom lines. Saat ini investor tidak hanya melihat tingkat keuntungan suatu perusahaan saja dalam pengambilan keputusan investasi melainkan melihat citra perusahaan. Pelaksanaan CSR oleh perusahaan harus selaras dengan norma-norma, nilai, dan keyakinan yang berlaku di masyarakat sehingga perusahaan akan mendapatkan legitimasi (Nègre, et al., 2017).. Perusahaan akan memiliki citra yang positif apabila telah memperoleh legitimasi.

Penelitian sebelumnya dilakukan oleh Sidhoum \& Serra (2017) menyatakan bahwa CSR berpengaruh positif pada nilai perusahaan. Semakin banyak item pengungkapan sosial yang diungkapkan bila diiringi dengan kualitas pengungkapan yang semakin baik, maka dapat meningkatkan nilai perusahaan. Perusahaan yang memiliki komitmen CSR dalam jangka panjang akan mengalami peningkatan harga saham yang lebih signifikan. Hasil penelitian tersebut sejalan dengan penelitian yang dilakukan Armika (2018), Citra (2017), Wulansari (2017) dan Ramadhani et al., (2017) bahwa CSR berpengaruh positif pada nilai perusahaan. Berdasarkan teori dan hasil penelitian tersebut dapat diajukan hipotesis sebagai berikut.

$\mathrm{H}_{1}$ : Corporate Social Responsibility berpengaruh positif pada nilai perusahaan.

Pentingnya aktivitas CSR menyebabkan perusahaan lebih memperhatikan aktivitas tanggung jawab sosialnya untuk meningkatkan nilai perusahaan (Fiona, 2017). CSR berperan sangat penting dalam meningkatkan nilai perusahaan. Nilai perusahaan dapat naik sebagai hasil dari peningkatan penjualan dengan cara melakukan berbagai kegiatan sosial di lingkungan sekitar perusahaan. Profitabilitas digunakan sebagai variabel moderating dalam penelitian ini karena secara teoritis semakin tinggi tingkat profitabilitas yang dicapai perusahaan maka semakin kuat pula hubungan pengungkapan sosial dengan nilai perusahaan (Sulistyaningsih, 2017).

Profitabilitas merupakan salah satu aspek penting yang dilihat dalam laporan keuangan. Tingkat profitabilitas yang semakin besar menunjukkan perusahaan mampu mendapatkan laba yang semakin besar, sehingga perusahaan mampu untuk meningkatkan aktivitas tanggung jawab sosial, serta mengungkapkan tanggung jawab sosialnya dalam laporan tahunan dengan lebih 
luas. Hasil penelitian tersebut sejalan degan penelitian Pratama (2016), Dinata (2018), Ariani et al., (2018). Berdasarkan teori dan penelitian sebelumnya, maka dapat diajukan hipotesis sebagai berikut:

$\mathrm{H}_{2}$ : Profitabilitas memperkuat pengaruh Corporate Social Responsibility pada nilai perusahaan.

\section{METODE PENELITIAN}

Lokasi penelitian ini dilakukan pada seluruh perusahaan pertambangan yang terdaftar di Bursa Efek Indonesia (BEI) periode 2016-2018. Objek penelitian ini adalah nilai perusahaan yang dipengaruhi Corporate Social Responsibility dan profitabilitas pada perusahaan sektor pertambangan yang terdaftar di BEI periode 2016-2018.

Populasi dalam penelitian ini adalah seluruh perusahaan sektor pertambangan yang terdaftar di BEI periode 2016-2018 yang berjumlah 43 perusahaan. Pengambilan sampel dalam penelitian ini menggunakan metode nonprobability sampling dengan teknik purposive sampling. Teknik analisis data yang digunakan dalam penelitian ini adalah Moderated Regression Analysis (MRA) dengan Uji Interaksi. Adapun model regresi ditunjukan dalam persamaan sebagai berikut :

$\mathrm{Y}=\alpha+\beta_{1} X_{1}+\beta_{2} X_{2}+\beta_{3} X_{1} \star X_{2}$

Keterangan :

$\mathrm{Y} \quad=$ Nilai Perusahaan

a $\quad=$ Konstanta

$\beta_{1} \quad=$ Koefisien regresi variabel Corporate Social Responsibility

$\beta_{2} \quad=$ Koefisien regresi variabel Profitabilitas

$\beta_{3} \quad=$ Koefisien regresi Interaksi antara CSR dengan Profitabilitas

$X_{1} \quad=$ Corporate Social Responsibility

$X_{2} \quad=$ Profitabilitas

\section{HASIL DAN PEMBAHASAN}

Statistik deskriptif disajikan untuk memberikan informasi mengenai karakteristik variabel-variabel penelitian, yaitu jumlah sampel, nilai maksimum, nilai minimum, nilai rata-rata dan standar deviasi. Hasil statistik deskriptif penelitian ini dapat dilihat pada Tabel 1. sebagai berikut:

Tabel 1. Hasil Uji Statistik Deskriptif

\begin{tabular}{lccccl}
\hline & $\mathrm{N}$ & Minimum & Maximum & Mean & $\begin{array}{l}\text { Std. } \\
\text { Deviation }\end{array}$ \\
\hline PBV & 33 & 0,67 & 3,84 & 1,4867 & 0,71189 \\
CSRDI & 33 & 0,33 & 0,76 & 0,4867 & 0,15001 \\
ROA & 33 & 0,00 & 0,24 & 0,0837 & $0 \quad 0,06562$ \\
CSRDI*ROA & 33 & 0,13 & 17,78 & 4,2275 & 4,37529 \\
\hline
\end{tabular}

Sumber: Data Penelitian, 2019

Nilai perusahaan dalam penelitian ini diukur menggunakan rasio Price to Book Value (PBV). Berdasarkan Tabel 1. nilai rata-rata PBV sebesar 1,4867 cenderung rendah dibandingkan dengan nilai maksimal 3,84 artinya rata-rata perusahaan belum mampu meningkatkan nilai perusahaan. Nilai standar deviasi 
sebesar 0,71189 lebih rendah dibandingkan nilai rata-rata. Hal ini menunjukkan bahwa sebaran data sudah merata atau perbedaan data satu dengan data yang lainnya tidak tergolong tinggi. Nilai minimum PBV sebesar 0,67 dimiliki oleh PT Harum Energy Tbk. pada tahun 2017. Nilai maksimum PBV sebesar 3,84 dimiliki oleh PT Golden Energy Mines Tbk. pada tahun 2017, dapat dikatakan bahwa perusahaan tersebut sudah mampu meningkatkan nilai perusahaannya.

Corporate Social Responsibiliy (CSR) dalam penelitian ini diukur menggunakan Corporate Social Responsibility Disclosure Index (CSRDI). Berdasarkan Tabel 1. nilai rata-rata CSRDI sebesar 0,4867 mendekati nilai maksimal sebesar 0,76 artinya rata-rata perusahaan sudah mengungkapkan CSR dengan baik. Nilai standar deviasi sebesar 0,15001 nilai ini lebih rendah dibandingkan nilai rata-rata. Hal ini menunjukkan bahwa sebaran data sudah merata atau perbedaan data satu dengan data yang lainnya tidak tergolong tinggi. Nilai minimum CSRDI sebesar 0,33 dimiliki oleh PT Harum Energy Tbk. pada tahun 2016. Nilai maksimum CSRDI sebesar 0,76 dimiliki oleh PT Aneka Tambang Tbk. pada tahun 2017, menunjukkan perusahaan sudah melakukan pengungkapan dengan maksimal.

Profitabilitas dalam penelitian ini diukur menggunakan rasio Return On Assets (ROA). Berdasarkan Tabel 1. nilai rata-rata ROA sebesar 0,0837 cenderung rendah dibandingkan dengan nilai maksimal sebesar 0,24 artinya rata-rata perusahaan belum mampu meningkatkan profitabilitas. Nilai standar deviasi sebesar 0,06562 lebih rendah dibandingkan nilai rata-rata. Hal ini menunjukkan bahwa sebaran data sudah merata atau perbedaan data satu dengan data yang lainnya tidak tergolong tinggi. Nilai minimum ROA sebesar 0,00 dimiliki oleh PT Aneka Tambang Tbk. pada tahun 2016. Nilai maksimum ROA sebesar 0,24 dimiliki oleh PT Bukit Asam Tbk. pada tahun 2018, dapat dikatakan bahwa perusahaan tersebut memiliki profitabilitas yang baik.

Interaksi profitabilitas dan CSR dari 33 sampel memiliki nilai rata-rata sebesar 4,2275, nilai ini cenderung rendah dibandingkan dengan nilai maksimumnya sebesar 17,78, sedangkan nilai minimumnya sebesar 0,13.

Pengujian normalitas data dalam penelitian ini dilakukan dengan uji KolmogorovSmirnov atau K-S dengan bantuan Software Statistic Package for the Social Science (SPSS) for Windows. Hasil dari uji normalitas disajikan dalam Tabel 2. sebagai berikut:

Tabel 2. Hasil Uji Normalitas

\begin{tabular}{lll}
\hline & & Unstandardized Residual \\
\hline $\mathrm{N}$ & & 33 \\
Normal Parametersa,b & Mean & 0,0000000 \\
& Std. Deviation & 0,32640498 \\
Most Extreme Differences & Absolute & 0,090 \\
& Positive & 0,060 \\
& Negative & $-0,090$ \\
Test Statistic & & 0,517 \\
Asymp. Sig. (2-tailed) & & 0,952 \\
\hline
\end{tabular}

Sumber: Data Penelitian, 2019 
Berdasarkan Tabel 2. nilai Asymp. Sig. (2-tailed) dari model persamaan yang diuji sebesar 0,952 lebih besar dari 0,05. Hal ini menunjukkan data yang digunakan dalam penelitian ini berdistribusi normal.

Uji autokorelasi bertujuan untuk menguji dalam model regresi linear ada korelasi antara kesalahan penggangu pada periode dengan kesalahan pengganggu pada periode $\mathrm{t}-1$ (sebelumnya). Untuk mendeteksi ada tidaknya autokorelasi dilakukan dengan menggunakan Uji Durbin-Watson (DW-Test) dengan ketentuan $\mathrm{du}<\mathrm{dw}<(4-\mathrm{du})$. Hasil uji autokorelasi disajikan dalam Tabel 3. sebagai berikut:

Tabel 3. Hasil Uji Autokorealasi

\begin{tabular}{cc}
\hline DW (Durbin Watson) & Keterangan \\
\hline 1,924 & $\mathrm{du}<\mathrm{dw}<(4-\mathrm{du})$ \\
\hline
\end{tabular}

Sumber: Data Penelitian, 2019

Berdasarkan Tabel 3. hasil uji autokorelasi menunjukkan nilai DW sebesar 1,924. Hasil tersebut dibandingkan dengan nilai tabel DW menggunakan nilai signifikansi 5\%, jumlah sampel (n) 33 dan jumlah variabel independen $2(k=2)$ diperoleh nilai $\mathrm{dL}=1,3212$ dan $\mathrm{dU}=1,5770$. Oleh karena $\mathrm{du}<\mathrm{dw}<4$-du yaitu $1,924<2,182<2,076$ maka dalam penelitian ini tidak terjadi gejala autokorelasi. Semua uji asumsi klasik telah memenuhi syarat maka uji nilai selisih mutlak dilanjutkan.

Uji heteroskedastisitas dalam penelitian ini menggunakan uji Glejser, uji Glejser dilakukan dengan meregresikan variabel bebas terhadap absolute residual. Jika tingkat signifikansi masing-masing variabel $>0,05$ maka dapat disimpulkan bahwa model regresi bebas mengandung adanya heteroskedastisitas (Ghozali, 2016: 138).

Tabel 4. Hasil Uji Heteroskedastisitas

\begin{tabular}{cc}
\hline Variabel & Sig. \\
\hline CSR & 0.757 \\
ROA & 0.871 \\
CSR*ROA & 0.801 \\
\hline
\end{tabular}

Sumber: Data Penelitian, 2019

Berdasarkan Tabel 4. maka dapat disimpulkan bahwa data terbebas dari heteroskedastisitas. Hal itu ditunjukkan dengan keseluruhan nilai variabel berada pada tingkat signifikansi $>0,05$.

Tabel 5. Hasil Moderated Regression Analysis (MRA)

\begin{tabular}{|c|c|c|c|c|c|}
\hline \multirow[b]{2}{*}{ Model } & \multicolumn{2}{|c|}{$\begin{array}{l}\text { Unstandardized } \\
\text { Coefficients }\end{array}$} & \multirow{2}{*}{$\begin{array}{l}\text { Standardized } \\
\text { Coefficients } \\
\text { Beta }\end{array}$} & \multirow[b]{2}{*}{$\mathrm{T}$} & \multirow[b]{2}{*}{ Sig } \\
\hline & B & Std. Error & & & \\
\hline (Constant) & 0,927 & 0,322 & & 2,878 & 0.007 \\
\hline CSR & 0,387 & 0,591 & 0.082 & 0,655 & 0.518 \\
\hline Profitabilitas & $-7,503$ & 3,238 & $-0,692$ & $-2,317$ & 0.028 \\
\hline CSR_Profitabilitas & 0,236 & 0,053 & 1,453 & 4,441 & 0,000 \\
\hline $\begin{array}{ll}\text { Adjusted } \mathrm{R}^{2} & =0,799 \\
\text { F Hitung } & =43,552 \\
\text { Sig F } & =0,000\end{array}$ & & & & & \\
\hline
\end{tabular}




$$
\mathrm{Y}=0,927+0,387 \mathrm{X}_{1-7,503} X_{2}+0,236^{X_{1} \star X_{2}}
$$

Nilai konstanta sebesar 0,927 memiliki arti apabila semua variabel independen konstan, maka nilai perusahaan akan naik sebesar 0,927 kali dari nilai buku perusahaan. Nilai koefisien regresi Corporate Social Responsibility (CSR) sebesar 0,387 memiliki arti jika Corporate Social Responsibility (CSR) meningkat sebesar 1 satuan (1 indeks), maka nilai perusahaan akan meningkat sebesar 0,387 kali dengan asumsi semua variabel independen lainnya konstan. Nilai koefisien regresi profitabilitas sebesar $-7,503$ memiliki arti jika profitabilitas meningkat sebesar 1 satuan (1\%), maka nilai perusahaan akan turun sebesar 7,503 kali dengan asumsi semua variabel independen lainnya konstan. Nilai koefisien regresi interaksi profitabilitas dan CSR sebesar 0,236 memiliki arti jika regresi interaksi profitabilitas dan CSR naik sebesar 1 satuan, maka nilai perusahaan akan meingkat sebesar 0,236 kali dengan asumsi semua variabel independen lainnya konstan.

Koefisien determinasi $\left(R^{2}\right)$ diukur untuk mengetahui presentase pengaruh variabel independen terhadap perubahan variabel dependen. Koefisien determinasi pada model regresi dilihat dari nilai Adjusted $\mathrm{R}^{2}$. Pada Tabel 5. nilai Adjusted $\mathrm{R}^{2}$ sebesar 0,799 atau 79.9 persen. Hal ini berarti bahwa variasi variabel nilai perusahaan yang diproksikan denga PBV dapat dijelaskan sebesar 79,9 persen oleh variasi variabel CSR dan profitabilitas sedangkan sisanya sebesar 20,1 persen dipengaruhi oleh variabel lain.

Uji kelayakan model (Uji F) digunakan untuk mengetahui apakah model regresi Moderated Regression Analysis (MRA) dalam penelitian ini layak digunakan atau tidak. Pada Tabel 5. nilai $\mathrm{F}$ hitung sebesar 43,352 dengan signifikansi 0,000. Nilai signifikansi tesebut lebih kecil dari level signifikansi 0,05. Jadi dapat disimpulkan bahwa model Moderated Regression Analysis (MRA) layak digunakan.

Berdasarkan Tabel 5. diperoleh nilai t hitung Corporate Social Responsibility (CSR) sebesar 0,655 sedangkan nilai t tabel sebesar 1,697 dan nilai signifikansi uji t yakni nilai $p$-value sebesar 0,518 lebih besar dari $a=0,05$ serta nilai koefisien regresi sebesar 0,387 . Ini berarti bahwa CSR tidak berpengaruh terhadap nilai perusahaan, sehingga hipotesis pertama dalam penelitian ini ditolak.

Berdasarkan penelitian yang dilakukan oleh Inastri (2017), Dewi, (2018) dan Retno (2017) menyatakan bahwa CSR tidak berpengaruh pada nilai perusahaan. Hasil penelitian ini tidak sesuai dengan teori legitimasi. Teori legitimasi menyatakan bahwa kegiatan CSR dilakukan agar memperoleh legitimasi dan akan meningkatkan reputasi perusahaan yang pada akhirnya akan berpengaruh pada nilai perusahaan (Retno, 2017). Hal ini berarti perusahaan yang mengungkapkan CSR belum tentu dapat meningkatkan nilai perusahaan dan perusahaan yang tidak mengungkapkan CSR belum tentu memiliki nilai perusahaan yang rendah.

Berdasarkan Tabel 5. diperoleh nilai t hitung interaksi profitabilitas dan Corporate Social Responsibility sebesar 4,441 sedangkan nilai $t$ tabel sebesar 1,697 dan nilai signifikansi uji t yakni nilai $p$-value sebesar 0,000 lebih kecil dari $\alpha=$ 0,05 serta nilai koefisien regresi sebesar 0,236 . Ini berarti bahwa profitabilitas 
memperkuat pengungkapan CSR terhadap nilai perusahaan, maka hipotesis kedua dalam penelitian ini diterima.

Hasil penelitian ini sejalan dengan penelitian yang dilakukan oleh Pratama (2016), Dinata (2018), dan Ariani et al., (2018) yang menunjukkan bahwa profitabilitas memperkuat pengaruh pengungkapan CSR pada nilai perusahaan. Profitabilitas merupakan salah satu aspek penting yang dilihat dalam laporan keuangan. Tingkat profitabilitas yang semakin besar menunjukkan perusahaan mampu mendapatkan laba yang semakin besar, sehingga perusahaan mampu untuk meningkatkan aktivitas tanggung jawab sosial, serta mengungkapkan tanggung jawab sosialnya dalam laporan tahunan dengan lebih luas. Penelitian ini sejalan dengan teori legitimasi yang menyatakan bahwa nilai perusahaan dapat ditingkatkan dengan peningkatan hasil penjualan yang akan meningkatkan laba melalui kegiatan atau kontrak sosial yang dilakukan perusahaan kepada masyarakat.

\section{SIMPULAN}

Penelitian ini dapat menjadi suatu hal baru untuk penelitian yang berhubungan dengan variabel Corporate Social Responsibility (CSR), nilai perusahaan, dan profitabilitas. Pengolahan data dilakukan dengan menggunakan Moderated Regression Analysis (MRA) untuk memperkirakan hubungan antara variabel variabel yang telah ditetapkan sebelumnya berdasarkan teori. Hasil penelitian ini dapat digunakan untuk memperkaya referensi yang berkaitan dengan Corporate Social Responsibility (CSR), nilai perusahaan, dan profitabilitas. Penelitian ini menghasilkan simpulan mengenai profitabilitas sebagai pemoderasi pengaruh pengungkapan Corporate Social Responsibility (CSR) pada nilai perusahaan.

Hasil dalam penelitian ini diharapkan dapat memberikan informasi mengenai pentingnya pengungkapan CSR dan meningkatkan profitabilitas sehingga nantinya dapat meningkatkan nilai perushaan. Penelitian ini berhasil membuktikan teori legitimasi yaitu jika semakin besar perhatian perusahaan terhadap lingkungan sekitar maka semakin tinggi kepedulian masyarakat terhadap kinerja mereka, sehingga tercipta citra positif dimata masyarakat yang diharapkan mampu meningkatkan laba perusahaan sehingga dapat meningkatkan nilai perusahaan.

\section{REFERENSI}

Ariani, R., Sitawati, R., \& Sam'ani. (2018). Pengaruh Pengungkapan CSR Dan GCG Terhadap Nilai Perusahaan Dengan Profitabilitas Sebagai Variabel Moderasi. Prima Ekonomika, 9(1), 38-47.

Armika, A. A. A. M. (2018). Pengaruh Pengungkapan Tanggung Jawab Sosial Pada Nilai Perusahaan Dengan Profitabilitas Sebagai Variabel Pemoderasi. E-Jurnal Akuntansi Universitas Udayana, 22(1), 80-107.

Citra, K. R. (2017). Pengaruh Kepemilikan Institusional, Kepemilikan Manajerial, Dan Pengungkapan Corporate Social Responsibility Terhadap Nilai Perusahaan Pada Perusahaan Manufaktur Yang Terdaftar Di Bursa Efek Indonesia. Jurnal Ilmiah Akuntansi Bisnis, 2(1). 
Dewi, A. A. A. T. W. (2018). Pengaruh Profitabilitas Pada Nilai Perusahaan Dengan Corporate Social Responsibility Sebagai Variabel Intervening. EJurnal Akuntansi Universitas Udayana, 22(2), 1557-1583.

Dinata, I. D. A. A. K. (2018). Profitabilitas Memoderasi Pengaruh Corporate Social Responsibility Dan Good Corporate Governance Pada Nilai Perusahaan. E-Jurnal Akuntansi Universitas Udayana, 24(1), 481-506.

Fibrianti, N. P. E. (2015). Pengaruh Hutang, Profitabilitas, Dan Tanggung Jawab Lingkungan Pada CSR Disclosure Perusahaan Pertambangan. E-Jurnal Akuntansi Universitas Udayana, 11(1), 99-114.

Fiona, J. (2017). Pengaruh Corporate Social Responsibility Disclosure Terhadap Firm Value Dimoderasi Oleh Good Corporate Governance. JOM Fekon, 4(1), 1570-1582.

Gaea. (2017). Corporate Social Responsibility. Retrieved October 20, 2018, from http://www.gaea.bg/about-GAEA/corporate-socialresponsibility.html

Ghozali, I. (2016). Aplikasi Analisis Multivariate Dengan Program Ibm SPSS 21 (8th ed.). Semarang: Badan Penerbit Universitas Diponegoro.

Image, W.. Sexy Killers. Retrieved June 24, 2019, from https://youtube.be/qlB7vg4I-To

Inastri, M. A. (2017). Pengaruh Penerapan Good Corporate Governance Dan Pengungkapan Corporate Social Responsibility Pada Nilai Perusahaan. E-Jurnal Akuntansi Universitas Udayana, 21(2), 1400-1429.

Indasari, A. P. (2018). Pengaruh Profitabilitas, Growth Opportunity, Likuiditas, Dan Struktur Modal Pada Nilai Perusahaan. E-Jurnal Akuntansi Universitas Udayana, 22(1), 714-746.

Jitmaneeroj, B. (2017). A Latent Variable Analysis Of Corporate Social Responsibility And Firm Value. Managerial Finance, 14(2), 344-358.

Kusumayanti, N. K. R. (2016). Corporate Social Responsibility Sebagai Pemediasi Pengaruh Ukuran Perusahaan, Profitabilitas Dan Leverage Pada Nilai Perusahaan. E-Jurnal Akuntansi Universitas Udayana, 15(1), 549-583.

Latupono, S. S. (2015). Pengaruh Corporate Social Responsibility terhadap Nilai Perusahaan: Good Corporate Governance Variabel Moderating. Junal Ilmu \& Riset Akuntansi, 4(8).

Lingga, V. P. (2019). Pengaruh Corporate Social Responsibility pada Nilai Perusahaan dengan Kinerja Lingkungan Sebagai Pemoderasi. E-Jurnal Ekonomi Dan Bisnis Universitas Udayana, 8.4, 413-442.

Makalew, S. I. Y. (2017). Pengaruh Kinerja Lingkungan Terhadap Kinerja Keuangan Perusahaan Dengan Pengungkapan Informasi Lingkungan Sebagai Variabel Mediasi. Skripsi Sarjana Jurusan Akunatnsi Pada Universitas Katolik Widya Mandala, 1-16.

Maqbool, S., \& Zameer, M. N. (2018). Corporate Social Responsibility And Fi Nancial Performance: An Empirical Analysis Of Indian Banks. Future Business Journal, 4(1), 84-93. https:/ / doi.org/10.1016/j.fbj.2017.12.002

Nahda, K., \& Harjito, D. A. (2011). Pengaruh Corporate Social Responsibility Terhadap Nilai Perusahaan Dengan Corporate Governance Sebagai Variabel Moderasi. Jurnal Siasat Bisnis, 15(1). 
Nègre, E., Verdier, M., Cho, C. H., \& Patten, D. M. (2017). J . Account . Public Policy Disclosure Strategies And Investor Reactions To Downsizing Announcements: A Legitimacy Perspective. Journal of Accounting and Public Policy, 239-257. https://doi.org/10.1016/j.jaccpubpol.2017.03.003

Pratama, G. L. (2016). Pengaruh Corporate Social Responsibility Terhadap Nilai Perusahaan Dengan Profitabilitas Sebagai Variabel Pemoderasi. eProceeding of Management, 3(3), 3432-3438.

Puspita, N. K. D. (2018). Pengungkapan Tanggung Jawab Sosial Memoderasi Pengaruh Profitabilitas Dan Ukuran Perusahaan Pada Nilai Perusahaan. E-Jurnal Akuntansi Universitas Udayana, 22(3), 2148-2176.

Ramadhani, A. R., Purnamawati, I. G. A., \& Sujana, E. (2017). Pengaruh Corporate Social Responsibility Dan Kepemilikan Manajerial Terhadap Nilai Perusahaan Dengan Profitabilitas Sebagai Variabel Moderating. EJournal S1 Ak Universitas Pendidikan Ganesha, 7(1).

Retno, D. (2017). Pengaruh CSR Dan Enviromental Performance Terhdap Nilai Perusahaan Dengan GCG Variabel Moderating. Jurnal Ilmiah Dan Ilmu Akuntansi, 6(11), 1-24.

Saham Online. Retrieved August 22, 2019, from https://www.sahamonline.id

Sari, R. A. I. (2016). Pengaruh Leverage, Profitabilitas, Size, Dan Growth Opportunity Terhadap Nilai Perusahaan. Jurnal Ilmu Dan Riset Manajemen, 5(10), 1-17.

Sidhoum, A. A., \& Serra, T. (2017). Corporate Social Responsibility And Dimensions Of Performance: An Application To U . S . Electric Utilities. Utilities Policy. https://doi.org/10.1016/j.jup.2017.06.011

Sulistyaningsih, S. (2017). Pengaruh Corporate Social Responsibility Terhadap Nilai Perusahaan Dengan Profitabilitas Sebagai Variabel Moderating. Seminar Nasional IENACO, 787-794.

Undang - Undang Perseroan Terbatas No. 40 Tahun 2007.

Wulansari, R. (2017). Pengaruh Corporate Social Responsibility Dan Good Corporate Governance Terhadap Nilai Perusahaan. Jurnal Ilmu Dan Riset Akuntansi, 6(8), 1-19. 